Jef Huysmans

School of Politics and International Relations

Queen Mary University of London

Jef.huysmans@qumul.ca.uk

Motioning the politics of security - the primacy of movement and the subject of security ${ }^{1}$ Jef Huysmans

1. For comments on earlier versions of this article, I would like to thank: Joao Nogueira, Samuel Singler, Vicki Squire, Martina Tazzioli, students taking my course Doing International Political Sociology. Movement Fracturing the Social and Political at the Winter School International Political Sociology PUC-Rio 8-12 July 2019, students attending my seminars on Fracturing movement, migration and community - Towards an international political sociology of life in motion at the University of Lapland 19-21 March 2019, audience members in the panel Doing International Political Sociology at the BISA Annual Conference, London, 12-14 June 2019, and my colleagues during the presentation of an earlier version in TheoryLab/Doing IPS Work in Progress Seminars at SPIR, QMUL (19 February 2020). 


\begin{abstract}
The article explores challenges that giving conceptual primacy to movement poses for thinking the politics of security. In security studies, there has been an intense interest in mobile phenomena and the nature of security techniques that seek to control, contain or steer them. However, when exploring how these mobile phenomena bear upon conceptions of politics and their contestation, the analytics tends to turn back to more static or sedentary categories and reference points. Against this background, the article develops an analytical framework for security and its politics that gives conceptual primacy to movement. The conceptual primacy of movement implies three key moves: (a) changing lines from enclosures and connectors to pathways, (b) shifting from understanding movement through positions and nodes to the continuity of movement, and (c) displacing architectural and infrastructural readings of the relations between movements with readings of continuously unfolding confluences of movements moving in relation to one another. Doing so displaces conceptions of movement as border crossings and networked connections with entangling movements moving in relation to one another. One of the implications for security studies is that taking such a point of view challenges the use of 'the subject of security', in terms of state sovereignty and the positioning of differential security claims hooked into group identity, as a key device for making security politically meaningful and contested. The article concludes that giving conceptual primacy to movement invites security studies to not limit itself to studying the politics of movement but also to motion politics.
\end{abstract}


This article explores what it means to give conceptual primacy to movement and its implications for critical security studies. A continuing interest in flows and motion has led to security knowledge mobilising social network analysis, focusing on governing logistical lines, deploying dataveillance and big data analytics, and displacing geopolitical threat analysis with analytics of risk and resilience among others. It also has led to an intensified focus on the security implications of matter and subjects moving including viruses, projectiles, atmospheric gasses, sea currents, migrants, and money. Movement is here often primarily understood as a phenomenon; things, organisms and people on the move that one can observe.

The question that has been less often asked is what happens if we give movement conceptual rather than phenomenological primacy in security knowledge $?^{2}$ The argument I develop here is that using a concept of life and matter as immanently in motion challenges one of the main vehicles for gaining political purchase on security practice in critical security studies: the subject of security. The concept of 'the subject of security' refers here not to the question of subjectivity and subjectivisation but more narrowly to a specific way in which we think of security practices as political practices. It structures political meaning in a double way: (a) through the structuring impact of state sovereignty and it's enclosing, and (b) by analytically varying whose security matters.(Walker 1997) Movement then turns political when linked to border practices of territorial units and to op-positions between identities - or, in other words, to borders, boundaries and positionality. Doing so anchors movement back into fixed configurations. This article explores how the question of politics opens up differently when giving conceptual primacy to movement.

2. I use a nominalist understanding of a concept as a device that enacts a problem through thought and naming and in doing so opens lines of changing the problem in distinctive ways.(Lury and Wakeford 2012, 7-8) I speak of 'conceptual primacy' to express that I am developing a knowledge interference rather than an ontology. I do intend neither to set out an alternative ontology expressing a universal being of being nor to give primacy to being over knowledge. I borrow such a position from Zourabichvili's reading of Deleuze.(Zourabichvili 2012) 
The main aim is to draw on Lucretian lines of thought to develop in critical security studies a conceptual inroad into addressing a challenge recently made in a collective discussion piece in International Political Sociology:

\footnotetext{
"Recent claims about networks and transversalities seem to capture many important empirical phenomena, but they probably imply a very different way of understanding politics than we have inherited from models of the contained polis that are expressed in the formation of states and the international system.” (Walker et al. 2018, 92)
}

Challenges to familiar conceptions of politics are not unfamiliar to critical security studies. For example, Ann McNevin observes in her study of the role of the Indonesian island Bintan in migration governance that "contemporary practices of border security threaten to outrun the explanatory capacity of the spatial (territorial) and subject (citizen/migrant) registers habitually employed to think through human mobility."(Mcnevin 2014, 295) Her argument is not that we should ditch borders or networks as concepts to account for movement in spatial terms. Nor does she argue that subject categories like citizenship and migrant have become insignificant. Instead she concludes that her case study shows that knowledges anchored in these categories render movement in relation to quite specific constellations of power which the lives being lived in movement 'outrun'. Lived movements exist in a multiplicity of relations that cannot be so easily brought back to sovereign territoriality and subject positions. They thus invite us to rethink movement in critical security studies and to explore if and how such rethinking opens the question of politics differently.

I propose that giving conceptual rather than phenomenological primacy to movement creates such a line of thinking. It invites exploring transversal conceptions of politics of security that replace borders with pathways, networks with entangling of pathways, and the force of architectural configuration with the force of confluences in which movements move in relation to one another in pedesis. Although much of the article focuses on introducing a specific framework for understanding the primacy of movement in security studies, it does so 
to show that such an approach shifts how the question of politics emerges in security studies. More specifically, it invites us to explore conceptions of politics of (in)security that are not analytically imagined through 'the subject of security'. I do this to open a line of thought that motions conceptions of politics.

I develop this approach in three sections. Section 1 introduces how security studies makes movement politically meaningful by relating it to state sovereignty and to differentially positioned subjects of security, thus giving enclosure and fixity primacy in its conception of politics. Section 2 and 3 develop what it means to give conceptual primacy to movement. Between them they set out a set of concepts that make sense of life and matter as motion. They invite an analytics of how security and its politics become meaningful as motion; an analytics in which confluences of movements moving displace the subject of security. In the conclusion, I explain briefly how the conception of movement developed in the article invites us to think the politics of security not as a politics of movement but as a motioning of politics. The article is primarily conceptual. Although I draw quite heavily on examples from the migration studies literature, the article is not meant to be an analysis of the politics of security in the migration area. It is a conceptual exploration of some of the implications for critical security studies of following what I will refer to as Lucretian lines of thought on movement. 


\section{$\underline{1 .}$ Movement, the subject of security and sedentary conceptions of politics}

Things and people moving are key for understanding security practice and the insecurities it enacts. The military threat of another state consists in armies crossing territory, airspace and seas. Warfare depends on maintaining logistical lines, moving supplies to an army on the move. The speed and triangular movement of ballistic nuclear weapons radically challenged the relevance of territorial distance for defence purposes. Arms trade and global transfer of weapon technology and know-how have remained a key matter of security concerns. And that is before we start widening insecurities to viruses, financial flows supporting violent groups, transnational travel of terrorists, data flows in cyber-networks, changes in global sea currents, people escaping violent conflicts, the vulnerability of supply lines of gas and oil, and so on. Despite much of security being focused on the defence and protection of state territory and state-bounded citizenship, significant parts of security practice operate through transnational or de-territorialised techniques such as global surveillance and dataveillance, mapping and intervening in transnational networks, controlling migration through differentially keeping people on the move, and monitoring and protecting transnational logistics and infrastructures. There certainly is no shortage of relations between motion and security practice.

It is therefore not surprising that there has been an intense interest in security studies in mobile phenomena and the nature of security techniques that seek to control, contain or steer them. (Amoore 2006, Aradau 2016, Aradau, Huysmans, and Squire 2010, Bigo 2008, Chamayou 2015, de Goede 2012, Leese and Wittendorp 2017, Hall Kindervater 2016, Walters 2004, Merriman et al. 2017) In the 1990s, with the demise of the Cold War, various issues of debate in security studies crystallised into what has been called new security studies (Buzan and Hansen 2009), a security studies liberated from what it saw as the constraints of Cold War thinking. It included: (a) intensifying variations in the primary account of the 
subject of security - i.e. deepening the conception of security by introducing reference objects competing with the primacy of the sovereign state; (b) giving primacy to the existence of multiple security sectors challenging a focus on war and military power; (c) foregrounding flows across state boundaries in threat definitions. All of these were present well before 1989-1991 but in the 1990s they were combined and foregrounded to create security studies as a distinct knowledge field in International Relations. The question of flows, things and people on the move, has been one of the central elements of these new security agendas.

More recently, a few calls have been made to explicitly align security studies more with mobility studies. (Aradau 2016, Leese and Wittendorp 2017, Basaran and Guild 2017, Salter 2013, Suliman 2018) Mobility studies refers to a paradigmatic move in sociology and human geography that prioritises researching how mobilities are transforming 'the social as society' into 'the social as mobility'. (Urry 2000, Adey et al. 2014) In security studies it translates into giving primacy to mobile phenomena such as drones, flows of money, movement of people over conflicts between sedentary categories like states and bounded communities. It is not simply a call for adding the former to the latter but for using mobile phenomena rather than relations between static units, and between them and their external environment, as the main analytical entry point for making security sociologically meaningful.

\subsection{The political primacy of state sovereignty}

Given the importance of things and people moving, it is at first sight somewhat surprising that when making security politically meaningful the analytics tends to turn to more static or sedentary categories and reference points. What I mean by 'politically meaningful' is the categories and points of view through which conceptions of politics are 
written into security knowledge so as to gain political purchase on securitising processes. ${ }^{3}$ (Huysmans 2014) In security studies, movement becomes a matter of concern particularly when challenging the territorialised organisation of politics. Even when it is recognised that borders do not properly enclose the polity or when security practice goes transversal, the spatio-temporal demarcations of state sovereignty often remain the key category through which these practices become politically meaningful. Therefore, giving primacy to people and things moving does not in itself give primacy to motion in the conception of politics. What is defended and challenged largely remain territorially positioned and enclosed political units.

A related but different mode of making movement political asks how things and people moving constitute political sites or polities. For example, one of the key meeting points Leese and Wittendorp identify in their call for a shared research agenda between critical security and mobility studies is a common interest in how movement is involved in the production of sovereignty and political community. (Leese and Wittendorp 2018, 174-75) The primary conception of politics thus remains enclosed polities, which movement helps to constitute. This primacy of sedentary conceptions of politics is equally present in a second shared interest between the two fields that they identify: the impact of technology on the velocities with which borders can be crossed. (Leese and Wittendorp 2018, 176) Here movement refers to going from one place to another, crossing borders that identify bounded polities. The political nature of mobility thus remains predicated upon enclosed political spaces across which movement takes place.

3. State sovereignty is such a constitutive concept of politics that organises much of security thinking. It helps explain why flows and movement are often treated not as constitutive forces of politics themselves but as forces threatening sovereign control based on territorial enclosure. (Walker 1990) Attempts to make humanity the constitutive concept of politics is one way of seeking to change this prioritising of state sovereignty. I am not referring here specifically to human security agendas which are about changing who or what has priority in conflicting demands for security. As a constitutive concept of politics, humanity rather refers to a distinct genealogy of how we envisage the where and how of politics and how such a conception of politics is worked into and through security practices, if at all. (Bartelson 2010) 
Each of these approaches locates movement in a world that is politically organised in spatially delineated polities. A central reason for why movement is reinscribed in such sedentary conceptions of politics is the hold that spatio-temporal demarcations of state sovereignty retain on imaginations of how something can be political in security studies. (Walker 1997, 1993, 2010) Mostly, the political analytics draws on references to sovereign states — or state-like units — and state institutions for understanding security phenomena. State borders remain a key reference point for studying the security implications and renditions of things moving. The flows can be demographic, cultural, economic, ecological but their political significance depends on how they bear upon and are shaped by territorially bounded state-like units. When drawing on fundamental rights and resources of democratic politics to question the securitisation of migration, the political significance is not in flows and movements themselves but in bounded institutional processes linked to traditions of enclosed democratic polities.(Guild 2009) When John Herz (Herz 1961) analyses the impact of atomic weapons, he highlights how they disrupt the significance of territorial size, depth and enclosure in security strategies because of the transversal operation of ballistic nuclear weapons - going up into the atmosphere and coming back down rather than crossing borders. The political significance is that in doing so they disrupt the political organisation of security into spatially delineated polities. The ballistic mobility of nuclear weapons is one of the key characteristics of 'the atomic age' that brings him to argue for moving towards a more global political organisation of security.

\subsection{The subject of security and the primacy of positioning}

Changing the subject of security from states to other collective entities and subjects has been a key move to gain critical purchase on inscriptions of security into categories of territorial sovereignty and statehood.(Walker 1997) Security studies has a long tradition of arguing about who or what is to be secured. The notion of 'the subject of security' expresses 
how the politics of security is grounded in disputes about whose security matters. I use the question of the subject of security in this particular sense in this article. It foregrounds two related questions: (a) the hold that the concept of the State has on our imaginations of political life and (b) conceptualising challenges to the primacy of the State by researching insecurities from the position of particular groups or identities. Should the protection of refugees or the vulnerabilities of migrants prevail over claims of territorial sovereignty or protection of citizens' rights? Should national security have priority over the security of the global ecological system? What happens to security if we take women's lives as the reference point for identifying security needs? How does human security practice prioritising the security of people over state security interfere in conflicts and with what consequences for whom? Although many of the issues that trigger these debates are related to people and things on the move — from migrations to global trade and pollution — their political dimension and the conflict between meanings of security is organised in terms of positioning who or what is the primary subject of security.

Such disputes about the subject of security are not simply about competing referent objects of security but also concern which subjects are authorised to define meaningful security and its alternatives. In other words, varying the subject of security also implies varying the subject of politics. This link has been particularly visible in feminist security studies and in attempts to foreground the voice of migrants as an authoritative voice in defining security. Feminist security studies is not simply a call for taking violences and insecurities as experienced by women more serious in national and global security agendas. It also seeks to give feminine points of view and women authority in debates about security and its alternatives. (Tickner 1992, Stern 2005, Wibben 2011) Similarly, foregrounding migrant stories and authorising migrants claiming their rights and the right to hold rights shifts their position in the analysis of the security-migration nexus from a subject that deserves to be 
made secure to a political subjectivity authorised to define what security is meaningful and not. (Brigden 2018, Innes 2016, Nyers 2006, Stierl 2019)

This combination of the subject of security as also a subject of politics is a major method in critical security studies to gain political purchase on the meaning of security. It creates disputes about both what (in)securities matter to whom and who can speak authoritatively about insecurities. (Booth 1991, Haftendorn 1991, Huysmans 2006, McSweeney 1999, Newman 2010, Tickner 1992, Walker 1997, Wibben 2011, Wæver et al. 1993) The political meaning of security does not derive from subjects or objects moving, however, but rather from the positioning of the subject of security through which distinct claims of protection are fixed. Similar to work that prioritises territorial sovereignty, introducing competing subjects of security makes movement politically significant by linking it to fixed positions and enclosed identities.

Such a conception that favours positioning and enclosed polities cannot help us to conceptualise politics as movement — or in other words, to motion the politics of insecurity. I do not want to undermine the significance of the subject of security to gain critical purchase on the concept of security. This mode of thought has been crucial for generating debates about the meaning of security as well as analyses of the political stakes in conflicting renditions of security. However, I think it is important for reasons set out in the introduction to follow through what is implied by giving conceptual primacy to movement to see how such a point of view challenges sedentary conceptions of the politics of insecurity based on the models inherited from the contained polis of the State and positioned collective subjects. 


\section{Giving conceptual primacy to movement}

If adding moving things and people more explicitly to security studies and prioritising how they are constitutive of political units does not really give primacy to movement in the sense I am developing here, what then does it mean to give movement conceptual primacy? ${ }^{4}$ The point of view I seek to introduce requires us to experiment with conceptualising every and all phenomena as motion and nothing but motion. It goes back to Lucretius' work $D e$ Rerum Natura in which matter is 'continuous and turbulent flow (flux) of movement without rest and without space or time'. (Nail 2019, 33) In Thomas Nails' reading, Lucretius is more radical than the Greek as well as modern atomist philosophies because the primacy of movement is for him not simply that atoms and particles continuously fall and swerve but that they themselves are movement. He speaks of matter itself as movement rather than movement as the continuous motion of some-thing (e.g. a particle or atom). (Nail 2018, 1-12)

Drawing on authors that work in this lineage of thought, I experiment with how conceptualising life as motion without stasis invites a distinct analytics of security. It is driven by an interest in making the transversal a normal mode of relating rather than one that gains it's meaning from transgressing a world of enclosed units.(Soguk and Whitehall 1999) Samid Suliman (Suliman 2018) called for a similar move in security studies by seeking to formulate a kinepolitical view of security.

\subsection{From borders to pathways; moving along lines rather than between places}

So, what is distinctive about conceptualising life and matter as always in-motion? A good starting point is Tim Ingold's work. (Ingold 2011) He aims at restoring 'life' to

4. The conceptual primacy of movement is not the same as some conceptions of nomadism for which movement is emancipatory or stands for freedom within a dialectic of flows and stasis, exchange and sovereignty.(Adey 2006,78 ) If everything is movement, then also control and governance are movement. 
anthropology by giving primacy to movement: 'It is of the essence of life that it does not begin here or end there, or connect a point of origin with a final destination, but rather that it keeps on going ...' (Ingold 2011,4) For Ingold, such an anthropology requires displacing the primacy of bounded space and enclosed communities with wayfaring. Wayfaring takes 'life as lived along lines' rather than across them. (Ingold 2011, xii, chapter 12) Matter and beings are conceptualised as inhabiting the earth through pathways and their intertwining into bundles of lines that express parts of continuous journeys. It is visualised as knots. Unlike demarcated spaces, knots are formed of lines moving in and out of them. They are thus formed of entanglings of pathways that remain in motion. In that sense, it invites knowledge that seeks to understand sites, events, developments as they are lived through rather than within or without.(Ingold 2011, 149)

Such a conception of movement differs from topographic understandings that organise movement in relation to bounded spaces. Bounded spaces are created when drawing circumferences on a blank surface - e.g. a circle. It comes into being through separating an inside from an outside. Circumferences turn 'the pathways along which life is lived into boundaries within which it is enclosed.' (Ingold 2011, 145) People, things, organisms dwell within or without the locales thus created, and, when the circumference is stretched into a zone, possibly in the liminal area between. Movement then becomes crossing from the outside to the inside and vice versa.

Such a shift from lines as static perimeters enclosing movement to lines as pathways (Ingold 2011, 148) changes how we understand processes of securitising. For example, in her work on migration policies and the security-migration nexus in the context of the EU, Martina Tazzioli (Tazzioli 2014) has argued extensively for developing non-cartographic counter-mapping techniques that thread migrant journeys through encounters between people. Migration is no longer known through numbers moving from one demarcated space to 
another crossing a border zone. Instead, it is known through multiple story fragments of embodied journeys and a multiplicity of experienced encounters that cannot be unified through a starting point and destination point or a repositioning from outside to inside (and vice versa). These journeys temporarily link multiple pathways of villagers, vehicles, migrants and so on and are characterised by their entangling rather than their location within an enclosed geographical or administrative space.

Methodologically, pathways and wayfaring invite studying security not through cartographic maps. One way of doing this is to study security through 'récits' — stories, narratives. Whereas topographic thought distributes units in positions of co-existence and separations between those positioned inside and outside enclosures, 'récits' thread journeys, encounters happening through moving. (de Certeau 1990 [1980], 170-189) Noelle Brigden threads moments of migrant movement to open what she refers to as the blackbox of the journey. It allows her to interrogate multiple insecurities as they emerge within the encounters during migrant journeys and the consequences for societies of the interactions happening when pathways cross. ${ }^{5}$ (Brigden 2018) Similarly, Scheel (Scheel 2019) foregrounds studying migration and its relation to security technologies and agencies through a multiplicity of encounters taking place by bodies on the move. Although they are not necessarily completely dropping topographic understandings of migration and security, these approaches allow for understanding the journeys as always in-motion and thus fractured never starting or ending; not fixed in topographic positions. As a result, EU Europe for example no longer appears as a homogeneous space differentiated from its environment

5. There is significant work on narratives and methodologies of narrative analysis in feminist security studies and in migration studies. (Wibben 2011, Stern 2005) (Johnson 2016, Innes 2016) They are similarly concerned with moving away from geopolitical readings of security and migration but they emphasise the experiences and everyday practices of particular subject positions - migrants and/or women in this case. The notion of narratives and journeys I am using here aims to foreground writing life as the knotting of pathways rather than foregrounding experiences and narrations tied to subject positions. William Walters (Walters 2015) makes a similar move in his concept of 'viapolitics' and the proposal to look in more detail at vehicles and the contentions about them rather than narratives as a method for studying the intertwining of pathways and how they create lives, places, and so on. 
through circumferences - i.e. borders and boundaries — but as a multiplicity of defracted knottings of multiple pathways. EU Europe as enacted by migrants, security technologies, and security professionals is then written as a collection of changing knots where pathways cross and wind into one another rather than as a territorial-administrative unit that imposes a cartographic governance of borders onto migrants. ${ }^{6}$

Giving conceptual primacy to movement thus implies letting go of defining the politics of security as an enactment of continuously dividing insides from outsides, the institutionalisation of the circumferences drawn and the challenges posed by life and matter seeking to redraw or transgress them. If Walker (Walker 1997, 69) is correct that state sovereignty and its spatio-temporal demarcations dominate imaginations of what it means to be political in security studies, wayfaring and pathways are then to be read either as not political in themselves — only becoming political when linked back to border politics — or as creating a challenge for how to understand politics as movement that cannot be locked back into sedentary conceptions of politics.

\subsection{Networks and connectors are not pathways}

There is a conception of movement in security studies that does not understand movement through crossing borders. It conceptualises movement as bridging distance between nodal points and structures it through networks. Ingold refers to it as a transport conception of movement.(Ingold 2011, 149-150) Such an approach significantly shifts the understanding of the politics of security. First, it turns movement into a matter of logistics aimed at organising the traversing of distance. Governing friction becomes a key political issue in this context. For example, not the crossing of borders is central to a transport understanding of migration but the 'smuggling hubs of departure' - e.g. the collection of 
vessels at shore — and the 'hotspots of arrival'. The spatialised points of departure and arrival (the nodal points) and the means available to move from one of these to the next take primacy. The politics of movement then becomes a struggle about friction. Some migrations are made as frictionless as possible; other migrations are limited and controlled by introducing frictions, such as the refusal to save people in need, seeking to reroute migrations through hazardous spaces, or making it difficult to obtain travel documents.

Lines as connecting nodal points in networks are not pathways, however. (Ingold 2011, 145-46) (Ingold 2007, 82) What matters in networks is the crossing of distance between nodal points, the carrying of 'stuff' from one point to the other, and not the lives lived during the transporting. Unlike network analysis, pathway analysis foregrounds how the Mediterranean, for example, exists as a meshing of pathways of multiple groups of migrants, sea currents, meteorological flows, humanitarian vessels, Frontex surveillance practices, and so on. It is not simply a frictional space - a border-zone of death, humanitarian insecurities, and criminalisation — that needs traversing. Neither is it just a surface upon which networks are drawn. It is a lived place enacted through the entanglements of pathways in which people die, currents set vessels adrift, migrants board military or civilian vessels in rescue operations, masses of data flow, commercial vessels move about, the weather changes, and so on. ${ }^{7}$ Movement becomes continuous rather than broken up in points and lines connecting them.

\subsection{The continuity of movement}

Networks are imagined through straight lines between points. Pathways, however, are a different kind of lines. They are continuous — not stopping and going between points. They

7. Andonea Dickson (Dickson 2021) developed a conception of the maritime and migration along these lines in her PhD thesis: 'Across deep seas and territorial waters: interrogating strategies of mobility control in maritime geographies.' 
cross over other pathways, entangle a little with them, then go off in another direction, and so on. Such a continuity of movement is central to what it means to give conceptual primacy to movement in the Lucretian lineage of thought. It is so central that networks and transport are understood as another mode of making movement intelligible through the primacy of stasis. Movement as going from point to point is not movement at all, for authors like Bergson (Bergson 1969).

Bergson explains the difference between connecting and continuous moving nicely in his discussion of Zenon's paradox. (Bergson 1969, 89) To create the paradox of Achilles not being able to overtake the tortoise, Zenon needs to organise movement spatially as points on a line. Achilles can never reach the tortoise because every time when he reached the point where the tortoise was, the tortoise has already moved on a little. Movement is thus made intelligible by being cut up in successive locations. Achilles objects, however. He emphasises that he does not run by jumping from spatial point to spatial point but rather performs an indivisible and continues series of acts — the run — that carries him through. Thinking movement along the lines of Zenon, is thinking as if movement consists of immobilities. The line becomes a series of dots with movement becoming the difference between one location and another, one position and another, either expressed in terms of time or in terms of location. Connecting difference is not movement for Bergson. What constitutes movement is the passage itself. Michel Serres expresses a similar idea of movement in his discussion of how to make sense of a football game. Giving primacy to movement introduces a point of view that reads the game through the ball's passings rather than the formal rules that define the game, the identity of the teams, or the bounded space of the field. The players are then not defined in terms of their group identity (the team they are on) or as positions within the field. Instead, they are brought into play by the pathways and entanglements that the passing of the ball creates. (Serres 1982 [1980], 224-230) 
Movement here is continuous in two senses: (a) it can only be accessed in the middle of its ongoings, that is, it cannot be thought through its point of origin and/or its end point; and, (b) it needs to be thought as passing and not a succession of positions. For Michel Serres, this means in linguistic terms favouring pre-positions - e.g. between, along — rather that positions - e.g. here, there. (Serres and Latour 1995 [1990], 102-103) One of the major implications of Ingold's, Bergson's and Serres's points of view is that to give primacy to movement is not simply a switch in priorities between sedentary and mobile or between fixity and flux. Rather, it requires taking everything as movement and nothing else. The moment we recognise non-motion — stasis — exists, movement slips through our fingers because we render it as positions in space or time - either by drawing lines as enclosing borders or as connectors between points. (Bergson 1969, 90) Translated into security studies, this means that giving primacy to movement in Bergson's, Serres' and Ingold's sense means neither moving from border studies to logistics nor from state sovereignty to network analysis. It asks instead for developing modes of thought that foregrounds movement as continuous passing.

At issue here is not just a difference between networks and the meshing of pathways. Moving from points to passings also further questions the positioning logic that 'the subject of security' implies. As explained earlier, the subject of security makes security meaningful by differentiating between coexisting positions, each identifying distinct security needs. Security thus becomes a distribution of reference points in space or time that fix insecurities into collective subjects. It gains meaning not through continuous passings - i.e. the lines of movements methodologically accessed by following the ball in a football game or the movement of people, vessels, sea currents, data in migration — but through an aligning of subject positions with distinctive security claims - i.e. the teams in football, humanitarian needs of refugees versus border security demands of citizens, women's insecurities and 
experienced violences versus the insecurities defined by the patriarchal state or family.

Taking movement as continuous invites us to think in terms of relations between movements rather than subjects. It also invites reconceptualising the structural dimensions of security practices from configurations of connections between positions to continuously unfolding entanglings between movements.

\section{$\underline{\text { 3. From configurations of movement to unfolding confluences of movements- }}$}

\section{moving}

So far, I have introduced that giving conceptual primacy to movement differs from the standard ways of understanding movement as border crossing and logistics. I have also indicated how it challenges the conception of the subject of security as a key conceptual device for gaining political purchase on the meaning of security. Taking everything as motion, however, leaves us with a serious question about how to conceptualise the 'structuration' or patterning of security and its politics. If security situations are enacted as always being in-motion, does that then mean that all enactments of insecurity are freefloating, random, without relational patterns? In other words, does it delete any notion of practices and situations being embedded in structural or relational forms? In critical security studies, seeking to understand the nature and transformations of such security forms whether as structure, dispositifs, assemblage, technology of governance, or instituted oppositions - are central to rendering visible how security practices, things, and sites exercise power. Circumferences separating insides from outsides and connectors between points creating networks allow for understanding how security and its politics take on specific configurations - i.e. patterns through which we get a sense of how practices, instances, technologies are not simply free flowing but co-exist in structured relations. Thinking security and its politics through the question of 'whose security matters?' does 
something similar by creating competing configurations of security claims, each linked to a distinctive subject position and the processes of its constitution. If the proposal here is to take an approach that everything is in-motion how do we conceptualise the patterning of and in movement without falling back on fixed structural configurations? The answer developed below proposes to conceptualise the patterning of movements as unfolding confluences of movements-moving. Confluences have three key interrelated characteristics: (a) movements entangle rather than configure, (b) the relation between movements is one of force rather than form and (c) entangling is a pedetic process.

Let's return to Ingold's lines. As explained in the previous section, wayfaring and pathways create patterns through the entangling of lines into densities of pathways crossing and swerving — Ingold's 'knots'. (Ingold 2011, 151-152). The patterning is one in fluctuation. In terms of Serres' reading of Lucretius' reflection on a spin top moving: 'It is in movement and at rest, it turns yet does not move, it rocks and is stable.' It is 'rest in and by movement itself.' (Serres 2018 [1977], 49) For example, counter-insurgency can be read through the knots emerging from military personnel swerving in relation to civilians, the travelling of sounds, movements of insurgents, bullets flying ... The violences are then given sense through the entangling of such movements moving across, between, through one another rather than the positioning of friends and enemies or the geography and infrastructural layout of the situation. The latter exist through the entangling movements rather than as the given conditions from within which we make sense of the movements that take place.

Unlike networks of connectors and nodal points, the entangling pathways are thus not really a configuration. They are a continuous unfolding of movements encountering, adjusting to, deviating from other movements. (Ingold 2011, 147-148) (Ingold 2015, 22) Such an understanding of movement does invite us to think the politics of security 
differently. Tazzioli’s conception of counter-mapping (Tazzioli 2014, 2015, Tazzioli and Garelli 2019, Tazzioli 2020, 146-151), to which we referred earlier, can be read as a proposal to think such a difference. Her counter-mapping takes multiple sites of struggle that are not cartographically represented but placed in an 'archive' of traces and memories of instances of journeys. ${ }^{8}$ The sites of struggle can be understood as knots, densities of movements swerving into and away from another. In doing so they generate fragile sites of entanglements. The 'archive' is then rendered as a composition of multiple knots that are connected by some journeys moving through more than one knot. Lines or pathways moving in relation to one another are central rather than linear connecting from start point - e.g. country of departure — to end point - e.g. country of arrival — or conflictual relations between positioned entities - e.g. migrants and the EU. This mode of counter-mapping is thus non-directional and a composition without centre defined through instances of movements moving in relation to one another. Such a mapping defracts the geographical space and security. Representations of movement by thick and thin arrows drawn on maps of states and borders, looking like military maps modelling an invasion, give way to instances of encounters. In addition, and more controversial in the critical studies of the migration-security nexus, it also defracts the collective subjectivities of migrants and sedentarians into multiple compositions of entanglements of pathways. That means that the conception of politics is not organised around the voice, vulnerabilities and/or interests of a collectivity called 'migrants' and another called 'citizens', for example.

Conceptual primacy of movement thus invites us to experiment with concepts of patternings that remain in-motion. Generic structural relations — configurations — cannot be taken as the points from which the multiplicity of living and being is rendered stable; the

8. Brigden and Mainwaring (Brigden 2018, Mainwaring and Brigden 2016) make similar points but do at places continue to work with a dialectic of mobility and immobility. Giving conceptual primacy to movement along the lines developed in this article aims at displacing such a dialectic with an immanent analytics of movements moving in relation to one another in turbulence. (Nail 2018) 
latter needs to be reconceptualised in terms that make patterning immanent and in motion. In Serres' physicalist terminology, ${ }^{9}$ we can speak of confluences to differentiate such patterning from systems that synthesise movements into solids and that favour hardness over the fragility and fluidity of life and things.(Serres and Latour 1995 [1990], 122) Confluent patterning emerges through continuous swervings, foldings, and passings of pathways in relation to one another. It means that we should think in terms of movements-moving, to borrow one of Erin Manning's terms. Such a conceptualisation displaces an analytics of form with one of force. (Deleuze and Guattari 2004 [1980], 407) It focuses on the force of pedetic processes of movements aligning to, cueing with, pushing away from other movements rather than the generic force of an architectural configuration. Let's follow Erin Manning into a metro station to get a sense of what this means.

"As the subway doors open, a subtle anticipatory shift in posture and tonality can be felt across the platform. Where before there seemed to be a relatively simple directionality, most of it tuned toward the subway doors, now a bidirectional tendency begins to form. These two movements can be quite frantic in their co-composition, especially when in addition people are running from the just-arrived train on the other side of the platform, hoping to make it onto the one you've been patiently waiting for. Yet very few collisions occur. And this is with many distractions - people listening to music with their earphones, friends talking, people running to get in before the doors slam. (...)

The choreography of collective movement is made possible by the inter-relation between the intervals the movement creates and the collective capacity to cue and align to them, in the moving. Cueing is an important activity in the relational field. It is not directly tied to volition or intentionality. It happens in the moving. Although it may feel like it is individuals cueing to one another, what is

9. Ingold uses the term 'meshworks' to express how knots are connected in mobile patterning.(Ingold 2011, 147-148) (Ingold 2015, 22) However, I am opting to introduce a more physicalist terminology of confluences in this section. The more anthropological language of pathways and knots emphasises how lives are lived through movement, how we inhabit the earth through movement(Ingold 2007, 81), which is important for bringing lived lives into a critical security studies that often focuses on technologies and routines of governance. However, for a political reading of mobile patternings, I feel we need to link this point of view also to a terminology that is more sensitive to questions of force in the patterning that takes place in movements moving in relation to one another. 
actually happening is that movement is cueing to a relational ecology in the making." (Manning 2016, 119-120)

The metro station is here given sense by means of how forces are exercised in-between movements. The configurations, such as the architecture of the metro station and barriers channelling movements in a particular way, are present but what is happening is not brought into knowledge by the form of the architectural, geographical or infrastructural layout. It is the cueing, aligning, resonating, distancing of movements which enact a continuously unfolding relationality. In such a reading, migration and its securitising, for example, are not given meaning through the institutional structure of border controls, the governing rationale of surveillance technologies, or an infrastructure of migrant routes but in the forces generated between the movements of border control agencies patrolling, migrants avoiding the patrolling, sea currents, moving into pathways of rescue ships, and so on.

The example of the metro station may read as if confluences are about avoiding conflicting movements and emphasise the harmonising of movements through attuning and cueing. That would be a wrong reading, however. As an example of migration in securitised seascapes would make immediately visible, the patterning takes place in movements cueing to other movements through a range of relations, including avoiding, clashing, folding into, crossing, attuning, distancing, and so on. The sea emerges as a geography of movements moving in relation to one another. ${ }^{10}$ The relation between these movements can take on a wide range of modalities — including clashing, conflicting, attuning — which means that confluences do not refer to smooth or harmonious co-existences of movements but the forces exercised in the swervings of co-existing movements.

Confluences of movements are immanently fragile. Change is continuous and takes place through the movements moving in relation to one another rather than through an 
external force that puts pressure on a given configuration. The patterning of movements is pedetic. Pedesis refers to 'some quantity (...) constantly undergoing small, random fluctuations' (Encyclopedia Britannica "Brownian motion" https://www.britannica.com/science/Brownian-motion [11 March 2020]). As pedesis, the entangling movements pattern but without finitude and predictability. In that sense, confluences always remain 'more-than' - i.e. more than a configuration or a probability of configurations of pathways. They refuse to let us know in advance what is to come. (Manning 2016, 127) That is why Manning speaks of the patterning being always in the making and why Serres (Serres 2018 [1977]) speaks of 'turbulence' and confluences being always both in rest and motion. Similarly, Ingold's pathways (Ingold 2011) are defined by the experiences of lives lived along them without the start- and end-point being of defining relevance or the traces of previous movements determining the movements that follow (determining understood as a method of rendering order by reducing the significance of disorderly motions).

The patterning is repetitive but without producing sameness because of constant small unpredictable fluctuations. Change is then conceptualised as taking place in and through continuous swervings between the movements that alter both the patterning between them and the movements themselves. In other words, as confluences patterning is immanently transforming rather than changing because of external forces disrupting a given configuration that channels movement. If turbulence is taken as a fundamental aspect of life and matter, then there is no need to introduce metaphysical notions of freedom or transcendental forces. Life and matter are self-composing.(Nail 2018, 8)

Following through on such a point of view is quite challenging for critical security studies. Much of the latter's criticality is invested in (a) making visible the reproductive and generic work of configurations (e.g. border control technologies; legal frameworks; 
embedded discursive framings; organisational architectures) and their impositions of exclusions, discriminations, violences on groups of people and (b) studying oppositional forces that mobilise disruptions of such configurations - i.e. resistances.

Giving conceptual primacy to movement in this sense also implies that force is not anchored in volitional or intentional subjects. The triangulated categories of intentionalityvolition-agency are displaced by movements working upon movements inflecting divergence in their entangling. (Manning 2016, 115-118, 130) In such a confluence of practices, the bodies of migrants, police, truck drivers, NGO activists, residence exist in a dynamic relation of their movements co-composing situations. (Manning 2016, 117-118) The patterning is given sense not through the agency of the subjects as such but the tendencies of the aligning, distancing, crossing, resonating of motions.

Following some things or people on the move can be a method to bring out confluences of movement. However, the object of analysis is not the 'objects' or 'subjects' moving who in their moving connect to other objects and subjects but rather how their moving attunes to, pushes against, swerves towards or away from other movements. In the earlier example of how to read a football game, the ball is not the movement but a methodological tool through which one can read the continuous unfolding patterning of the game as movements working upon movements. For example, one can start by following several migrants in how they pass through a Hotspot but it is not the migrants as subjects that are central for conceptualising the hotspot but the force that is generated in-between the multiple movements taking place within and through the hotspot. It invites an understanding of politics that works with forces emerging in the interval — the in-between — of the movements. For example, for Erin Manning, politics is then about co-composing dissonances within and through movements moving in relation to one another rather than oppositions between groups or distributions of speed and friction.(Manning 2016, 115-118) 
Thinking in terms of confluences as proposed here differs from studies that focus on the formation of subjectivity. For the latter, subjects exist through the processes of subjectivation or performing subjectivities rather than as pre-given entities that simply reenact themselves. By foregrounding processes through which subjects are made into subjects, such approaches also question the centrality of intentionality-volition-agency. However, they do not necessarily de-subjectivise the conception of politics. Particularly when subjectivation slips into the formation of subjectivity, the processes of subjectivation become political when the subjects enact themselves as collective subjects — sometimes understood as intersectional subjects, i.e. with multiple intersecting identities but still as identitarian subjects - and in security analysis, as subjects of insecurity. In that case, the politics of security return to a politics of the subject of security: whose security matters and who is authorised to speak insecurities that matter?

Some would say that there is no politics without subjects and we are therefore bound to rework conceptions of politics through conceptions of the subject. In light of McNevin's (McNevin 2017), Tazzioli's (Tazzioli 2020, 2014) and others' understandings of migration and its governance, however, I do think it is important to linger with the primacy of movement. It is a lineage of thought through which we can try to understand how that what is taking place in the sites they study requires us to rethink how we bring security practices into political language as a transversal politics. (Walker et al. 2018)

Developing such a point of view is thus not simply an intellectual exercise. It speaks to needs for rethinking politics in light of contemporary situations. For example, migrants being on the move and being moved around by security governance seriously undermines the conditions required for migrants to become a collective political subject in the sense of either a collective social movement or a people. Tazzioli explores this impossibility extensively in the context of EU borderzones. In these zones, migrants co-exist as multiplicities 
characterised by their only-temporary co-presence and divisibility — as a heterogenous and temporal collective patterning — rather than as 'a people' or 'a population'. (Tazzioli 2020, 15-42) The proposal to think in terms of unfolding confluences of movement - of mobile patterning taking place when movements-moving entangle — aims at providing a set of conceptual pointers to start making sense of situations like these that invite a desubjectivising approach, an approach that does not centre politics on the question of positioned collective subjects. ${ }^{11}$

\section{Conclusion: motioning the politics of security?}

If it is correct that the contemporary is intensely enacted in motion, then it seems important for critical security studies to ask what it means to give analytical primacy to movement and how it impacts on conceptions of the politics of security. In this article, I drew on Lucretian lines of thought to develop a distinctive take on what it means to give conceptual primacy to movement. Three key moves define the approach: (a) shifting lines from enclosures and connectors to pathways, (b) understanding movement as continuity rather than covering distance between points or positions, and (c) displacing architectural and infrastructural readings of the relations between movements with continuously unfolding confluences of movements moving in relation to one another. Such an understanding of movement has implications for how we conceptualise the politics of security. It challenges analysing

11. In this article I focused on how giving primacy to movement requires changing lines from borders and connectors to pathways and working with confluences rather than configurations. Such an approach, of course, also invites following through on the question of the subject. What would it mean to motion the subject, to understand the subject as emerging through confluent foldings of movements-moving? Or, does working with the primacy of movement, de-subjectivise the politics of insecurity in such a way that concepts of the subject, subjectivation or subjectivity are no longer key analytical categories through which political sense is inscribed into security? I have to leave these questions unanswered here. They demand more than introducing processual conceptions of the subject that focus less on positioning collective groups and more on the formation or performance of subjectivity. They require engaging in more depth than I can at the moment with work that engages the question of the subject in detail from similar lines of thought that I have introduced so far. I am thinking of work like Braidotti's nomadic approach to the question of the subject (Braidotti 2006, 1994) or Tazzioli's re-visiting of the concept of 'the mob' (Tazzioli 2020, 15-42). 
security practices in terms of borders, bordering and border crossings material and ideational generic configurations of securitising, for example. I focused in particular on how giving primacy to movement makes it difficult in critical security studies to sustain 'the subject of security' as a key conceptual device for gaining political purchase on security practice and knowledge. The loss of 'the subject of security', implies a loss of two interrelated conceptions of how critical security studies invests politicality in its knowledge:

I. the spatio-temporal demarcations of state sovereignty as the reference point for conceptualising the where and how of politics

II. connecting insecurities to differential subject positions, thus allowing for disagreements and conflicts between different conceptions of security. This 'loss' is not a minor issue. Indeed, as Walker (Walker 1997, 2010) has long argued, the conception of politics invested in security knowledge hinges on how the modern political subject is conceived and re-conceived in terms of who or what needs or deserves to be secured. If that is the case, the understanding of movement developed here may simply have lost politics altogether and thus be a major 'depoliticising' move, creating exactly the opposite of what I called for in the introduction.

Such a conclusion would not be out of the ordinary. Concepts of politics tend to have bounded space or unities as a necessary condition, even in works that focus on movement. For example, one of the key theorists of movement and speed, Paul Virilio, argued that the dominance of movement and speed turns societies into societies without place which for him are societies without rights. (Virilio 2001, 80-81, quoted in Merriman 2012 p. 51) Rights claims require bounded institutional sites — jurisdictions and public spheres — where people gather to claim rights in line with set procedures. The dominance of movement thus undermines core political institutions. 
Such readings suggest that although we can motion the social, motioning the political is something else. Yet, the latter is precisely what the Lucretian lines of thought invite us to explore in critical security studies. If life and matter are motion and nothing but motion, then also political life and matter are motion. The motioning of politics is not the same as the politics of movement. The latter explores how movement - mobile practices, technology, ideas and so on — bear upon or play a significant role in familiar units and repertoires of politics, how mobility becomes an object of politics, and how it affects distributions of political power. ${ }^{12}$ Here, movement becomes political through its challenges to and constitutive bearing upon conceptions of politics inherited through the history of sovereignty and territorialised bounded polities. Motioning politics, on the other hand, refers to conceptualising politics itself as motion. It invites experimenting with conceptions of transversal politics in which the politics of security is conceptualised in terms of unfolding forces of entangling movements in motion and the turbulences which they enact. The question is how to make political sense of a world of confluences without halting political movement analytically by inserting a dialectic between a mobile social and an immobile political and/or by lodging entangled forces of movements-moving back into collectivised subjects and identities.

In motioning politics, the site of the border, for example, emerges not first of all as an expression of sovereign politics but one site among many where multiple movements move in relation to one another and move on, as Umut Ozguk has recently shown in this journal. (Ozguc) The point is not that there are no border sites but rather how we conceptualise such statist border sites if we change the line from circumferences, and the political configuration(s) they fix, to the politics of co-composing pathways and their turbulent entangling in unfolding confluences. 
Giving conceptual primacy to movement as proposed here, offers a way to start exploring such conceptions of the politics of security in which movement can be political without having to be re-fixed to conceptions of enclosed polities and positioned collective subjects linked to a history of the state and the international system. It is an invitation to develop conceptions of transversal politics of security that are not in the first instance engaging how worlds full of movement impact on instituted conceptions of politics in security practice but that seek to motion the conception of politics itself.

Bibliography

Adey, P. (2006) "If Mobility Is Everything Then It Is Nothing: Towards a Relational Politics of (Im)Mobilities." Mobilities 1 (1):75-94.

Adey, P. (2017) Mobility. second ed. London: Routledge.

Adey, P, Bissell D, Hannam K, Merriman P, and Sheller M, eds.) (2014) The Routledge Handbook of Mobilities. Abingdon: Routledge.

Amoore, L. (2006) "Biometric Borders: Governing Mobilities in the War on Terror." Political Geography 25 (3):336-351.

Aradau, C. (2016) "Political Grammars of Mobility, Security and Subjectivity." Mobilities 11 (4):564-574.

Aradau, C, Huysmans J, and Squire V. (2010) "Acts of European Citizenship: A Political Sociology of Mobility." Journal of Common Market Studies 48 (4):945-965.

Bartelson, J. (2010) "The Social Construction of Globality." International Political Sociology 4 (3):219-235.

Basaran, T, and Guild E. (2017) "Mobilities, Ruptures, Transitions." In Basaran T, Bigo D, Guittet E-P and Walker RBJ (eds.) International Political Sociology. Transversal Lines, Abingdon: Routledge: 272-285. 
Bergson, H. (1969) La Penseé Et Le Mouvant. Essais Et Conférences. Paris: Les Presses universitaires de France.

Bigo, D. (2008) "Globalized (in)Security: The Field and the Ban-Opticon." In Bigo D and Tsoukala A (eds.) Terror, Insecurity and Liberty, Abingdon: Routledge: 10-48.

Booth, K. (1991) "Security and Emancipation." Review of International Relations 17 (4):31326.

Braidotti, R. (1994) Nomadic Subjects. Embodiment and Sexual Difference in Contemporary Feminist Theory. New York: Columbia University Press.

Braidotti, R. (2006) Transpositions. On Nomadic Ethics. Cambridge: Polity.

Brigden, NK. (2018) The Migrant Passage: Clandestine Journeys from Central America. Ithaca: Cornell University Press.

Buzan, B, and Hansen L. (2009) The Evolution of International Security. Cambridge: Cambridge University Press.

Chamayou, G. (2015) A Theory of the Drone. Translated by Lloyd J. New York: The New Press.

de Certeau, M. (1990 [1980]) L'invention Du Quotidien. 1. Arts De Faire. Paris: Gallimard.

de Goede, M. (2012) Speculative Security. The Politics of Pursuing Terrorist Monies. Minneapolis: University of Minnesota Press.

Deleuze, G, and Guattari F. (2004 [1980]) A Thousand Plateaus. Capitalism and Schizophrenia. Translated by Massumi B. London: Continuum.

Dickson, A. (2021) "Across Deep Seas and Territorial Waters: Interrogating Strategies of Mobility Control in Maritime Geographies."Doctoral thesis, School of Politics and International Relations, Queen Mary University of London.

Guild, E. (2009) Security and Migration in the 21st Century. Cambridge: Polity.

Haftendorn, H. (1991) "The Security Puzzle: Theory-Building and Discipline-Building in International Security." International Studies Quarterly 35 (1):3-17.

Hall Kindervater, K. (2016) "The Emergence of Lethal Surveillance: Watching and Killing in the History of Drone Technology." Security Dialogue 47 (3):223-238.

Herz, JH. (1961) International Politics in the Atomic Age. New York: Columbia University Press.

Huysmans, J. (2006) The Politics of Insecurity. Fear, Migration and Asylum in the Eu. London: Routledge.

Huysmans, J. (2014) Security Unbound. Enacting Democratic Limits, Critical Issues in Global Politics. Abingdon: Routledge.

Ingold, T. (2007) Lines: A Brief History. London: Routledge.

Ingold, T. (2011) Being Alive. Essays on Movement, Knowledge and Description. London: Routledge.

Ingold, T. (2015) The Life of Lines. London: Routledge.

Innes, AJ. (2016) "In Search of Security: Migrant Agency, Narrative, and Performativity." Geopolitics 21 (2):263-283.

Johnson, HL. (2016) "Narrating Entanglements: Rethinking the Local/Global Divide in Ethnographic Migration Research." International Political Sociology 10 (4):383-397.

Leese, M, and Wittendorp S, eds.) (2017) Security/Mobility. Politics of Movement. Manchester: Manchester University Press.

Leese, M, and Wittendorp S. (2018) "The New Mobilities Paradigm and Critical Security Studies: Exploring Common Ground." Mobilities 13 (2):171-184. 
Lury, C, and Wakeford N. (2012) "Introduction. A Perpetual Inventory." In Lury C and Wakeford N (ed.^eds.) Inventive Methods. The Happening of the Social., Abingdon: Routledge: 1-24.

Mainwaring, C, and Brigden N. (2016) "Beyond the Border: Clandestine Migration Journeys." Geopolitics 21 (2):243-262.

Manning, E. (2016) The Minor Gesture. Durham: Duke University Press.

Mcnevin, A. (2014) "Beyond Territoriality: Rethinking Human Mobility, Border Security and Geopolitical Space from the Indonesian Island of Bintan." Security Dialogue 45 (3):295-310.

McNevin, A. (2017) "Learning to Live with Irregular Migration: Towards a More Ambitious Debate on the Politics of 'the Problem'." Citizenship Studies 21 (3):255-274.

McSweeney, B. (1999) Security, Identity and Interests. A Sociology of International Relations. Cambridge: Cambridge University Press.

Merriman, P, Peters K, Adey P, Cresswell T, Forsyth I, and Woodward R. (2017) "Interventions on Military Mobilities." Political Geography 56 (1):44-52.

Nail, T. (2018) Lucretius I. An Ontology of Motion. Edinburgh: Edinburgh University Press.

Nail, T. (2019) Being and Motion. New York: Oxford University Press.

Newman, E. (2010) "Critical Human Security Studies." Review of International Relations 36 (1):77-94.

Nyers, P. (2006) "Taking Rights, Mediating Wrongs: Disagreements over the Political Agency of Non-Status Refugees." In Huysmans J, Dobson A and Prokhovnik R (ed.^eds.) The Politics of Protection. Sites of Insecurity and Political Agency, Abingdon: Routledge. 48-67.

Ozguc, U. "Rethinking Border Walls as Fluid Meshworks." Security Dialogue. doi: $10.1177 / 0967010620939389$.

Salter, MB. (2013) "To Make Move and Let Stop: Mobility and the Assemblage of Circulation." Mobilities 8 (1):7-19.

Scheel, S. (2019) Autonomy of Migration? Appropriating Mobility within Biometric Border Regimes. Abingdon: Routledge.

Serres, M. (1982 [1980]) The Parasite. Baltimore: John Hopkins University Press.

Serres, M. (2018 [1977]) The Birth of Physics. Translated by Webb D and Ross W. London: Rowman \& Littlefield.

Serres, M, and Latour B. (1995 [1990]) Michel Serres with Bruno Latour. Conversations on Science, Culture and Time. Translated by Lapidus R. Michigan: The University of Michigan Press.

Soguk, N, and Whitehall G. (1999) "Wandering Grounds: Transversality, Identity, Territoriality, and Movement." Millennium 28 (3):675-698.

Steinberg, P, and Peters K. (2015) "Wet Ontologies, Fluid Spaces: Giving Depth to Volume through Oceanic Thinking." Environment and Planning D: Society and Space 33 (2):247-264.

Stern, M. (2005) Naming Security - Constructing Identity. Mayan-Women in Guatemala on the Eve of 'Peace'. Manchester: Manchester University Press.

Stierl, M. (2019) Migrant Resistance in Contemporary Europe. Abingdon: Routledge.

Suliman, S. (2018) "Mobilising a Theory of Kinetic Politics." Mobilities 13 (2):276-290.

Tazzioli, M. (2014) Spaces of Governmentality. Autonomous Migration and the Arab Uprisings. London: Rowman \& Littlefield. 
Tazzioli, M. (2015) "Which Europe? Migrants' Uneven Geographies and Counter-Mapping at the Limits of Representation." Movements: Journal for critical migration and border studies $1(2): 1-20$.

Tazzioli, M. (2020) The Making of Migration. London: Sage.

Tazzioli, M, and Garelli G. (2019) "Counter-Mapping, Refugees and Asylum Borders." In Mitchell K, Jones R and Fluri JL (eds.) Handbook on Critical Geographies of Migration, Cheltenham: Edward Elgar: 397-409.

Tickner, JA. (1992) Gender in International Relations. Feminist Perspectives on Achieving Global Security. New York: Columbia University Press.

Urry, J. (2000) Sociology Beyond Societies. Mobilities for the Twenty-First Century. London: Routledge.

Virilio, P. (2001) "Speed-Space: Interview with Chris Dercon." In Armitage J (ed.) Virilio Live: Selected Interviews., London: Sage: 69-81.

Wæver, O, Buzan B, Kelstrup M, and Lemaitre P. (1993) Identity, Migration and the New Security Agenda in Europe. London: Pinter.

Walker, RBJ. (1990) "Security, Sovereignty, and the Challenge of World Politics." Alternatives 15 (1):3-27.

Walker, RBJ. (1993) Inside/Outside: International Relations as Political Theory. Cambridge: Cambridge University Press.

Walker, RBJ. (1997) "The Subject of Security." In Williams MC and Krause K (eds.) Critical Security Studies. Concepts and Cases., London: UCL Press: 61-81.

Walker, RBJ. (2010) After the Globe, before the World. Abingdon: Routledge.

Walker, RBJ, Shilliam R, Weber H, and du Plessis G. (2018) "Collective Discussion: Diagnosing the Present." International Political Sociology 12 (1):88-107.

Walters, W. (2004) "Secure Borders, Safe Haven, Domopolitics." Citizenship Studies 8 (3):237-260.

Walters, W. (2015) "Migration, Vehicles, and Politics: Three Theses on Viapolitics." European Journal of Social Theory 18 (4):469-488.

Wibben, ATR. (2011) Feminist Security Studies. A Narrative Approach. Abingdon: Routledge.

Zourabichvili, F. (2012) Deleuze: A Philosophy of the Event. Translated by Aarons K. Edinburgh: Edinburgh University Press. 